Journal of Computer Science 5 (6): 435-439, 2009

ISSN 1549-3636

(C) 2009 Science Publications

\title{
Strengthening of Corrosion-Damaged Reinforced Concrete Beams with Glass Fiber Reinforced Polymer Laminates
}

\author{
A. Leema Rose, K. Suguna and P.N. Ragunath \\ Department of Civil and Structural Engineering, \\ Annamalai University, Chidambaram-608 001, India
}

\begin{abstract}
Problem statement: This study showed the results of an experimental investigation on the strengthening of corrosion damaged reinforced concrete beams with unidirectional cloth glass fiber reinforced polymer (UDCGFRP) laminates. Approach: All the beam specimens $150 \times 250 \times 3000 \mathrm{~mm}$ were cast and tested for the present investigation. One beam specimen was neither corroded nor strengthened to serve as a reference. Two beams were corroded to serve as a corroded control. A reinforcement mass loss of approximately 10 and $25 \%$ were used to define medium and severe degrees of corrosion. The remaining two beams corroded and strengthened with GFRP. Results: The test parameters included first crack load, first crack deflection, yield load, yield deflection, service load, service deflection, ultimate load and ultimate deflection. Based on the results it was found that GFRP Laminates had beneficial effects even at the corrosion-damaged stage. Conclusion/Recommendations: The UDCGFRP laminated beams showed distinct enhancement in ultimate strength and ductility by 72.37 and $49.49 \%$ respectively.
\end{abstract}

Key words: Corrosion, reinforced concrete, strengthening, UDCGFRP laminates

\section{INTRODUCTION}

The problem of deterioration of concrete structures due to corrosion of steel reinforcement has received worldwide attention. Even though current codes of practice provide recommendations and precautions to avoid corrosion, evidence of corrosion of steel in concrete continues to be reported in the field situations. There are numerous references to studies carried out to investigate the structural strength of corrosion damaged RC beams ${ }^{[1-3]}$. Uomoto ${ }^{[4]}$ subjected several small RC beams reinforced with a single $16 \mathrm{~mm}$ rebar to accelerated corrosion using an impressed current and found that rebar corrosion has pronounced effect on the structural strength of RC beams than it does on the yield strength of the rebar. This result was attributed to the loss of bond between rebar and concrete due to cracking in concrete resulting from the expansive forces of the corrosion products. All the specimens were tested in flexure after corrosion and the results showed that un-corroded beams failed in flexure; while corroded beams exhibited a shear-bond failure at a load range of $67-95 \%$ as compared to un-corroded beams. It was concluded that the critical point in strength degradation occurs when longitudinal cracks form along the steel bars. Umoto ${ }^{[4]}$ suggest that increasing the concrete cover decrease diffusion of chloride ions, but also to prevent crack formation along the reinforcing bars.

Al-Sulaimani et al.$^{[5]}$ performed a total of 54 pullout tests of 10, 14 and $20 \mathrm{~mm}$ which were corroded to various degrees ranging from $0-14 \%$ mass loss. The author concluded that bond strength increased up to 50, 33 and $25 \%$, respectively, for 10,14 and $20 \mathrm{~mm}$ rebar at about $1 \%$ corrosion. Beyond $1 \%$ corrosion, bond strength decreased, dropping below the bond strength of un-corroded rebar only when the first surface corrosion cracks were detected. The effects of rebar corrosion on the structural characteristics of RC beams are well documented ${ }^{[6,7,9]}$.

Lee et $a l .{ }^{[8]}$ studied the characteristics of four RC beams subjected to accelerated corrosion and subsequently repaired with CFRP laminates externally bonded to the tension face. Specimens were $200 \times 250 \times 2400 \mathrm{~mm}$ and were reinforced with three $13 \mathrm{~mm}$ rebar at both top and bottom and with $6 \mathrm{~mm}$ stirrups at $50 \mathrm{~mm}$ spacing. The specimen with the tension rebar corroded to $10 \%$ mass loss achieved an ultimate strength of $85 \%$ than that of a un-corroded specimen and experienced failure due to loss of bond. Two corroded specimens were repaired with CFRP laminates after corrosion and showed an ultimate strength of 141 and $143 \%$ that of a un-corroded

Corresponding Author: A. Leema Rose, Department of Civil and Structural Engineering, Annamalai University, Chidambaram-608 001, India 
specimen and experienced failure due to tensile rupture of the CFRP laminates.

A promising application of composite materials is in the strengthening and repair of Reinforced Concrete (RC) structures. Many researchers have shown that concrete repair using FRP laminates is very successful in restoring or increasing the strength of concrete members. A further promising aspect of FRP repair is the prevention of deterioration due to rebar corrosion by confinement of the concrete member ${ }^{[8-10]}$. By strengthening concrete members with FRP laminates, concrete spalling and cracking caused by the expansive forces of the corrosion products may be delayed or even prevented.

The results of different studies discussed above strongly suggest that the corrosion cracking around the steel rebar is a fundamental component contributing to the loss of structural strength. This implies that if corrosion cracking can be prevented, or at least decreased, a certain degree of structural strength may be maintained in a corroding RC beam. This research derives such a relationship based on experimental data.

\section{MATERIALS AND METHODS}

The specified 28 day compressive strength of concrete used was $29.7 \mathrm{MPa}$ with a maximum aggregate size of $20 \mathrm{~mm}$ and a w/c ratio of 0.48 . The longitudinal steel reinforcement provided has $415 \mathrm{MPa}$ yield strength and Uni-directional cloth glass fiber reinforced polymer (GFRP) sheets with $3 \mathrm{~mm}$ thickness used for this investigation had a tensile strength of 451.5 MPa, an elastic modulus of $17365.38 \mathrm{MPa}$ and an ultimate elongation of $2.6 \%$.

Figure 1 shows the reinforcement details of the beam specimen. It consisted of two $10 \mathrm{~mm}$ diameter bars at the top and two $12 \mathrm{~mm}$ diameter bars at the bottom. Shear reinforcement consisted of $8 \mathrm{~mm}$ diameter stirrups at $150 \mathrm{~mm}$ spacing. The bottom reinforcing steel was extended $50 \mathrm{~mm}$ beyond the end of concrete face for the purpose of making external electrical connections.

Details of the test program are given in Table 1. A total of four beams were subjected to accelerated corrosion (10 and 25\%). Following the corrosion phase,
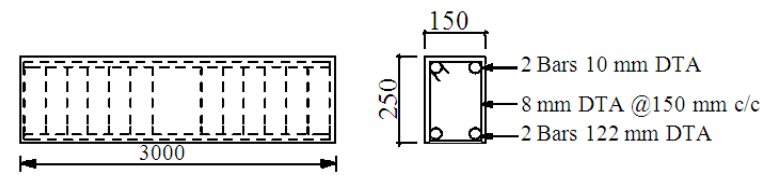

Fig. 1: Reinforcement details of the beam specimen
UDCGFRP laminates having $3 \mathrm{~mm}$ thickness were bonded to the tension face, with the fiber orientation in the longitudinal direction. One of the specimens was kept as a control specimen and was neither strengthened nor does corroded (virgin).

Accelerated corrosion: All specimens were subjected to accelerated corrosion. Figure 2 represents the accelerated corrosion setup. The four specimens were placed in a tank where $3.5 \% \mathrm{NaCl}$ solution was used as an electrolyte. The solution level in the tank was adjusted to slightly exceed the concrete cover plus reinforcing bar diameter to ensure adequate submersion of the longitudinal reinforcement.

The specimens were incorporated with a direct current power supply with an output of 11 Amps; thereby achieving theoretical steel weight loss of 10 and $25 \%$. According to Faraday's law:

$$
\Delta \mathrm{w}=\frac{\mathrm{A}_{\mathrm{m}} \cdot \mathrm{I} \cdot \mathrm{t}}{\mathrm{Z} \cdot \mathrm{F}}
$$

Where:

$\Delta \mathrm{W}=$ Mass loss due to corrosion

$\mathrm{A}_{\mathrm{m}}=$ Atomic mass of iron $(55.85 \mathrm{~g})$

I $=$ Corrosion current in amps

$\mathrm{t}=$ time since corrosion initiation $(\mathrm{sec})$

$\mathrm{Z}$ = valence(assuming that most of rust product is due to $\mathrm{Fe}(\mathrm{OH})_{2}, \mathrm{Z}$ is taken as 2$)$

$\mathrm{F}=$ Faraday's constant [96487 coulombs (g/equivalent)]

Table 1: Details of the test program

\begin{tabular}{llll}
\hline Specimen & $\begin{array}{l}\text { Level of } \\
\text { corrosion }(\%)\end{array}$ & $\begin{array}{l}\text { Type of } \\
\text { GFRP }\end{array}$ & $\begin{array}{l}\text { GFRP } \\
\text { thickness (mm) }\end{array}$ \\
\hline Virgin & No corrosion & --- & 0 \\
A 10\% & 10 & --- & 0 \\
A 10 UDC 3 & 10 & UDC & 3 \\
A 25\% & 25 & --- & 0 \\
A 25 UDC 3 & 25 & UDC & 3 \\
\hline
\end{tabular}

Note: A 10\%, A25\%, UDC3 refers to degrees of corrosion damage at 10 and $25 \%$ and UDC $3 \mathrm{~mm}$ thick respectively

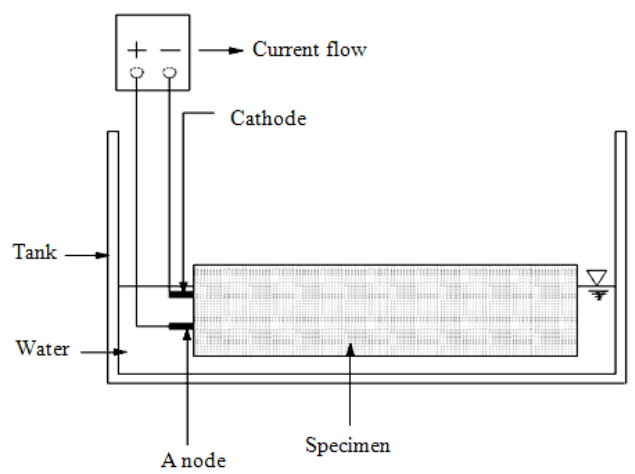

Fig. 2: Schematic of accelerated corrosion set-up 
Thus, by knowing the original mass of the rebar and the total current of the mass loss, the duration of corrosion activity can be determined. The specimens were prepared for GFRP lamination by removing all loose materials on the soffit of the rectangular beam by applying wire brush and roughened with a surface grinding machine. Two component room temperature curing epoxy adhesive was used for bonding the laminates. The laminated specimens were cured for a period of 7 days.

Test procedure: The beams were tested under twopoint loading in a loading frame capacity of $750 \mathrm{KN}$. The deflections were measured at mid-span and load points using mechanical dial gauges of $0.01 \mathrm{~mm}$ accuracy. The crack widths were measured using crack deflection microscope with a least count of 0.02 . The curvature measurement was also done using dial gauges placed over the compression face of the beam at and near to the support points. The deflections, curvature and crack width were measured at each load stage. The loading was continued until failure. The details of test set up are shown in Fig. 3.

\section{RESULTS}

The test results on the load and deflection properties of the specimens are reported in Table 2. The ductility indices of test beams are presented in Table 3 . The first crack loads were obtained on visual examination. The service loads were obtained from the ultimate loads with the usual partial safety factors. The yield loads were obtained (by inspection) corresponding to the stage of loading beyond which the loaddeflection response was not linear. The ultimate loads were obtained corresponding to the stage of loading beyond which the beam would not sustain additional deformation at the same load intensity. The deflection capacity is defined as the deflection of the beam at failure. The load deflection responses of the specimens are shown in Fig. 4 and 5.

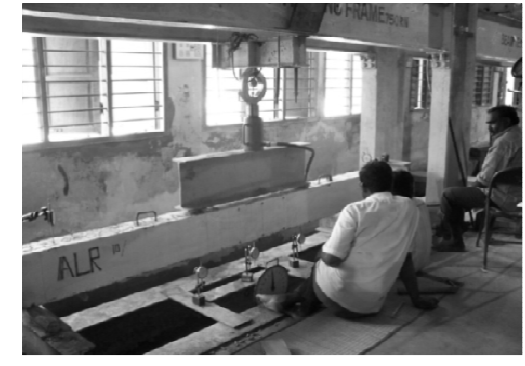

Fig. 3: Test setup

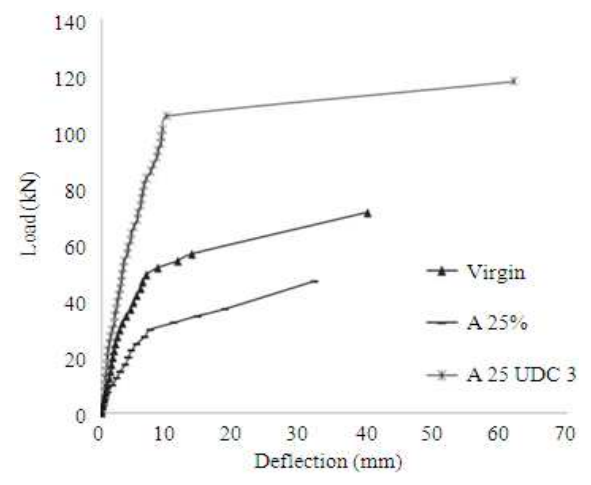

Fig. 4: Load-deflection response for $10 \%$ corrosion damaged beams

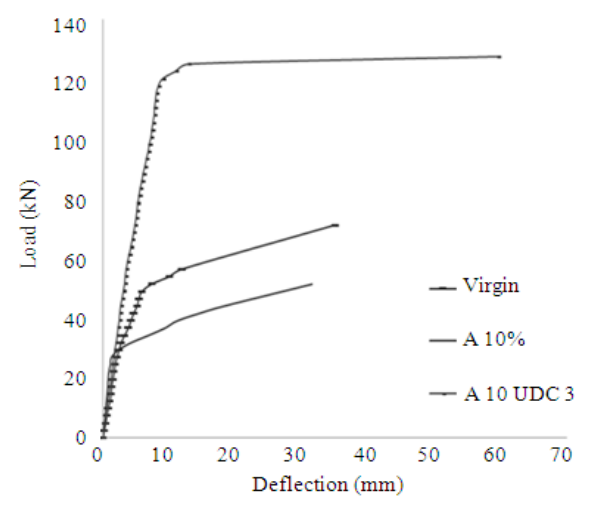

Fig. 5: Load-deflection response for $25 \%$ corrosion damaged beams

Table 2: Test results

\begin{tabular}{|c|c|c|c|c|c|c|c|c|c|}
\hline \multirow[b]{2}{*}{ Specimen } & \multicolumn{2}{|c|}{ First crack stage } & \multicolumn{2}{|c|}{ Yield stage } & \multicolumn{2}{|c|}{ Service load stage } & \multicolumn{2}{|c|}{ Ultimate stage } & \multirow[b]{2}{*}{$\begin{array}{l}\text { Maximum crack } \\
\text { width }(\mathrm{mm})\end{array}$} \\
\hline & $\begin{array}{l}\text { Load } \\
(\mathrm{kN})\end{array}$ & $\begin{array}{l}\text { Deflection } \\
(\mathrm{mm})\end{array}$ & $\begin{array}{l}\text { Load } \\
(\mathrm{kN})\end{array}$ & $\begin{array}{l}\text { Deflection } \\
(\mathrm{mm})\end{array}$ & $\begin{array}{l}\text { Load } \\
(\mathrm{kN})\end{array}$ & $\begin{array}{l}\text { Deflection } \\
(\mathrm{mm})\end{array}$ & $\begin{array}{l}\text { Load } \\
(\mathrm{kN})\end{array}$ & $\begin{array}{l}\text { Deflection } \\
(\mathrm{mm})\end{array}$ & \\
\hline Virgin & 26.98 & 2.36 & 51.50 & 8.43 & 47.41 & 6.50 & 71.123 & 40 & 1.20 \\
\hline A $10 \%$ & 19.62 & 0.83 & 34.34 & 7.75 & 34.34 & 7.75 & 51.500 & 36 & 1.24 \\
\hline A $25 \%$ & 12.26 & 2.20 & 29.43 & 7.25 & 31.09 & 10.56 & 46.590 & 32 & 1.30 \\
\hline A10UDC3 & 34.35 & 2.39 & 117.72 & 9.50 & 85.03 & 6.66 & 127.500 & 68 & 0.88 \\
\hline A25UDC3 & 31.88 & 1.86 & 105.45 & 9.75 & 78.48 & 6.19 & 117.700 & 62 & 1.04 \\
\hline Virgin & 26.98 & 2.36 & 51.50 & 8.43 & 47.41 & 6.50 & 71.123 & 40 & 1.20 \\
\hline $\mathrm{A} 10 \%$ & 19.62 & 0.83 & 34.34 & 7.75 & 34.34 & 7.75 & 51.500 & 36 & 1.24 \\
\hline A $25 \%$ & 12.26 & 2.20 & 29.43 & 7.25 & 31.09 & 10.56 & 46.590 & 32 & 1.30 \\
\hline A10UDC3 & 34.35 & 2.39 & 117.72 & 9.50 & 85.03 & 6.66 & 127.500 & 68 & 0.88 \\
\hline A25UDC 3 & 31.88 & 1.86 & 105.45 & 9.75 & 78.48 & 6.19 & 117.700 & 62 & 1.04 \\
\hline
\end{tabular}


Table 3: Ductility indices

\begin{tabular}{llcc}
\hline Specimen & Deflection ductility & Curvature ductility & Energy ductility \\
\hline Virgin & 4.74 & 7.87 & 7.87 \\
A10\% & 4.41 & 6.64 & 6.64 \\
A25\% & 4.64 & 8.40 & 8.40 \\
A10UDC3 & 7.15 & 12.17 & 12.17 \\
A25UDC3 & 6.35 & 10.59 & 10.59 \\
\hline
\end{tabular}

\section{DISCUSSION}

At the first crack stage, the corroded strengthened specimens exhibit an increase up to $27.28 \%$ compared to the virgin specimen. However the strength decreased by an average of $54.55 \%$ for corroded un-strengthened specimens.

At the service load stage, the corroded strengthened specimens exhibit an increase up to $79.35 \%$ at $10 \%$ and $65.53 \%$ at $25 \%$ mass loss respectively, compared to the virgin beam. However the strength decreased by an average of 27.56 and $34.42 \%$ for 10 and $25 \%$ degrees corrosion damage respectively, for corroded un-strengthened specimens.

At the yield load level, the corroded strengthened specimens exhibited an increase up to $128.58 \%$ compared to the virgin specimen. However, the strength decreased by an average of $37 \%$ for corroded unstrengthened specimens.

At the ultimate load level, the corroded strengthened specimens exhibit an increase up to $79.27 \%$ at $10 \%$ and $69.49 \%$ at $25 \%$ mass loss respectively, compared the virgin beam. However the strength decreased by an average of $27.58 \%$ and $34.49 \%$ for $10 \%$ and $25 \%$ degrees corrosion damage respectively, for corroded un-strengthened specimens. Based on the test results, it was found that GFRP laminates beneficial effects even at the corrosiondamaged stage.

The deflection at yield load stage, UDCGFRP laminated beams exhibit a decrease of $64.23 \%$ at $10 \%$ mass loss and $62.45 \%$ at $25 \%$ mass loss, when compared to the corroded control beam.

The deflection at service load stage, UDCGFRP laminated beams exhibit a decrease of $65.58 \%$ at $10 \%$ mass loss and $76.06 \%$ at $25 \%$ mass loss, when compared to the corroded control beam.

The deflection at the ultimate stage, UDCGFRP laminated beams exhibit a decrease of $23.72 \%$ at $10 \%$ mass loss and $23.30 \%$ at $25 \%$ mass loss, when compared to the corroded control beam.

It is clear from Table 3 that the corroded-GFRP strengthened specimens showed lesser crack width when compared to the control specimen, the maximum reduction being 54.6\%. The deflection ductility performance of the corroded strengthened specimens was improved by an average of $49.49 \%$ when compared to the control specimen. But in the case of corroded unwrapped beams, the ductility values got reduced marginally.

\section{CONCLUSION}

Based on the test results the following conclusions are drawn:

- GFRP laminates properly bonded to the tension face of RC beams can enhance the Ultimate strength substantially. The UD GFRP strengthened beams exhibit an increase of up to $79.27 \%$ in Ultimate strength for $10 \%$ steel mass loss, compared to the control specimen and up to $65.49 \%$ in Ultimate strength for $25 \%$ steel mass loss

- The deflection got reduced at all load levels in GFRP strengthened beams. At the ultimate stage, UDCGFRP laminated beams exhibit a decrease of $23.72 \%$ at $10 \%$ mass loss and $23.30 \%$ at $25 \%$ mass loss, when compared to the corroded control beam

- UDCGFRP laminated beams show enhanced ductility. The increase in deflection ductility was found to be $62.13 \%$ at $10 \%$ mass loss and $36.85 \%$ at $25 \%$ mass loss

\section{REFERENCES}

1. Schiecl, P. and M. Raupach, 1997. Laboratory studies and calculations on the influence of crack width on chloride-induced corrosion steel in concrete. ACI Mater. J., 94: 56-62. http://cat.inist.fr/?aModele $=$ afficheN\&cpsidt $=2647$ 632

2. Hussain, S.E., Rasheeduzzafar, A. Al-Musallam and A.S. Al-Gahtani, 1995. Factors affecting threshold chloride for reinforcement corrosion in concrete. Cement Concrete Res., 25: 1543-1555. http://cat.inist.fr/?aModele $=$ afficheN\&cpsidt $=3691$ 037

3. Andrade, C., M.C. Alonso and J.A. Gonzalez, 1990. An initial effort to use the corrosion rate measurements for estimating rebar durability, ASTM., STP-6: 29-37.

http://md1.csa.com/partners/viewrecord.php?reque ster $=$ gs\&collection $=$ TRD\&recid $=200163006573 \mathrm{C}$ $\mathrm{E} \& \mathrm{q}=\&$ uid $=787261508 \&$ setcookie $=\mathrm{yes}$

4. Uomoto, T., K. Tsuji and T. Kakizawa, 1984. Deterioration mechanism of concrete structures caused by corrosion of bars. Trans. Jap. Concrete Inst., 6: 163-70. 
5. Al-Sulaimani, G.J., M. Kaleemullah, I.A. Basunbul and A. Razeeduzzafar, 1990. Influence of corrosion and cracking on bond behavior and strength of reinforced concrete members. ACI Struct. $\quad$ J., $\quad 87$ : 630-638. http://www.concrete.org/PUBS/JOURNALS/OLJD etails.asp?Home $=$ SJ\&ID $=2732$

6. Sherwood, E.G. and K.A. Soudki, 1998. Durability of concrete beams repaired by carbon fiber reinforced polymer laminates subjected to accelerated rebar corrosion. Proceedings of the CSCE Annual Conference, (CSCE'98), 3b, Halifax, Nava Scoutia, pp: 663-672.

7. Mangat, P.S. and M.S. Elgarf, 1999. Flexural strength of concrete beams with corroding reinforcement. ACI Struct. J., 96: 149-158. http://www.concrete.org/PUBS/JOURNALS/OLJD etails.asp?Home $=\mathrm{SJ} \& \mathrm{ID}=606$
8. Lee, H.S., F. Tomosawa, Y. Masuda and T. Kage, 1997. Effect of CFRP sheets on flexural strengthening of RC beams damaged by corrosion of tension rebar. Proceedings of 3rd International Symposium on Non Metallic (FRP) Reinforcement for Concrete Structures, Oct. 23-23, Society of Civil Engineers, Tokyo, Japan, pp: 435-442.

9. Sherwood, E.G. and K.A. Soudki, 1998. Repair of corroded RC beams with carbon FRP sheets. Proceedings of the 5th International Conference on Composites Engineering, July 5-11, Las Veegas, Nevada, pp: 819-20.

10. Almusallam, A.A., A.S. Al-Gahtani, R. Aziz, F.H. Dakhill and A. Rasheeduzzafar, 1996. Effect of reinforcement corrosion on flexural behavior of concrete slabs. J. Mater. Civil Eng., 8: 123-127. http://direct.bl.uk/bld/PlaceOrder.do?UIN=011891 998\&ETOC $=$ RN\& from=searchengine 